\title{
Growth and carbohydrate status of Pyrus communis L plantlets inoculated with Glomus sp
}

\author{
F Rapparini *, R Baraldi, G Bertazza \\ Istituto di Ecofisiologia delle Piante Arboree da Frutto, CNR, Via Gobetti 101, 40129 Bologna, Italy
}

(Received 30 July 1996; accepted 23 September 1996)

\begin{abstract}
Summary - The effects of an arbuscular mycorrhizal fungus (Glomus sp) on development and carbohydrate metabolism of micropropagated plantlets of a pear clonal rootstock (OH $\mathrm{OF} 51$ ) were examined during the first vegetative growth and at the beginning of the second growing year. Plant growth was assessed in terms of stem height, leaf number, root length, fresh and dry weight of the whole plant, stem, leaves and root mass at different times following inoculation. The levels of soluble (fructose, glucose, sucrose and sorbitol) and insoluble (starch) sugars were analyzed in stems, leaves and roots using gas-chromatographic techniques. Inoculation with Glomus sp was effective in promoting plant growth causing a strong increase in shoot height, root length and a greater growth rate of dry matter. Colonization of rootstock roots with Glomus sp altered the carbohydrate metabolism and partitioning within the plant.
\end{abstract}

carbohydrate / pear rootstock / arbuscular mycorrhizae / micropropagation

Résumé - Croissance et état des glucides chez des microplantes de Pyrus communis $L$ inoculées avec Glomus sp. Les effets d'un champignon mycorhizogène à arbuscule (Glomus sp) sur la croissance et sur le métabolisme glucidique d'un porte-greffe micropropagé de poirier $(\mathrm{OH} \times \mathrm{F} 51)$ ont été examinés pendant les premiers stades et au début de la deuxième année de développement. La croissance des plantes a été évaluée, à différentes périodes après inoculation, par des mesures de hauteur de tige, de nombre de feuilles, de longueur de racines et de poids de matière fraîche et sèche. Le contenu en glucides solubles (fructose, glucose, saccharose et sorbitol) et insolubles (amidon) a été mesuré dans les tiges, les feuilles et les racines par chromatographie gazeuse. L'inoculation avec Glomus $\mathrm{sp}$ s'est révélée efficace pour stimuler la croissance des plantes en induisant une forte augmentation de la hauteur des tiges, de la longueur des racines et du taux de matière sèche par rapport aux témoins. La colonisation des racines de porte-greffes par Glomus sp a provoqué aussi un changement au niveau du métabolisme des glucides et de leur répartition dans la plante.

glucides / porte-greffe de poiriers / mycorhizes arbusculaires / micropropagation 


\section{INTRODUCTION}

Arbuscular mycorrhizal (AM) symbiosis has been widely found highly effective in enhancing plant growth and increasing transplant survival of in vitro propagated fruit rootstocks, through an improved nutrient uptake, increased resistance to pathogens and better root development (Gianinazzi et al, 1989; Berta et al, 1990). These beneficial effects of AM colonization are dependent on photosynthate supply by the host. Owing to this carbon demand by the fungus upon the host, carbohydrate status of the plants seems to be altered by the symbiosis. Several studies have reported changes in carbon partitioning and carbohydrate levels in a wide range of host species during the AM infection process (reviewed by Cooper, 1984; Harris and Paul, 1987). Nemec and $\mathrm{Vu}$ (1990) indicated that reducing sugars, sucrose and starch content in leaves of 6-month-old AM sour orange were higher than in those of control plants according to previous results (Snellgrove et al, 1982; Dixon et al, 1988). In contrast, recently Trimble and Knowles (1995) reported that total soluble sugar concentration in leaves and roots of AM cucumber plants were, respectively, lower and higher than in non-AM plants.

The present study was performed with the aim to further investigate the effects of $A M$ infection on development and carbohydrate metabolism of micropropagated plantlets of a pear clonal rootstock $(\mathrm{OH} \times \mathrm{F} 51)$ during the early vegetative phases after inoculation and at the beginning of the second growing year.

\section{MATERIALS AND METHODS}

\section{Experimental material}

Rooted microplants of a pear clonal rootstock $\mathrm{OH} \times \mathrm{F}$ 51 (Pyrus commuis L), provided by Vitroplant-Cesena (Italy), were outplanted from agar medium into $2 \mathrm{~L}$ plastic boxes (30 microplants per box) containing a sterile peat-sand mixture substrate $(1: 1, \mathrm{v} / \mathrm{v})$ and weaned under growth chamber conditions $(60-80 \%$ relative humidity, $23-25^{\circ} \mathrm{C}, 16 \mathrm{~h}$ photoperiod at $60 \mu \mathrm{mol} \mathrm{m}-2 \mathrm{~s}^{-1}$ photosynthetic photon flux density [PPFD]). After 1 month, plantlets were transplanted to individual pots filled with $600 \mathrm{~mL}$ of a sterile soil, sand and peat $\operatorname{mix}(2: 1: 1, \mathrm{v} / \mathrm{v} / \mathrm{v})$ and were inoculated or not with $1 \mathrm{~g} /$ pot of finely chopped root fragments from 3month-old clover (Trifolium pratense $\mathrm{L}$ ) pot cultures infected with a Glomus species. After transplant, pots were placed in a controlled-temperature greenhouse $\left(18-25^{\circ} \mathrm{C}\right.$ day/night) where plants were grown under natural photoperiod for 3 months. On a clear day, the midday photosynthetically active radiation (PAR) measured at plant shoots was about $500-700 \mu \mathrm{mol} \mathrm{m}^{-2}$ $\mathrm{s}^{-1}$. Pots were then transferred to nursery condition in full sun until the end of the vegetative growth which occurred at the end of September. Subsequently, plants were covered with straw and kept in the open over winter. The experiment was terminated 10 months after inoculation when the plantlets, after replacing them in a warm greenhouse, began the second growing year. Plants were watered daily with tap water and fertilized weekly with $20 \mathrm{~mL} /$ pot of Long Ashton solution lacking phosphorus. The experiment was set up in a completely random design with 50 replicates per treatment.

\section{Plant growth}

Every 1-2 weeks plant growth was assessed in terms of stem height and the number of fully expanded leaves during the entire experimental period. Plants were harvested 2, 3, 4, 5 and 10 months following inoculation. At harvest nine randomly selected plants per treatment were washed, weighed, divided into roots, stems and leaves and frozen in liquid nitrogen. After lyophilization the dry weight of each plant component was determined. The relative growth rate for dry matter (RGR DM) was calculated from the slope of In DM between 2-3, 3-4 and 4-5 months after inoculation. Root length was determined utilizing an image analysis based system. The image was digitized with a ELVIS board and processed with Chameleon Image Analysis Software (Sky Instruments Ltd, UK).

\section{Arbuscular mycorrhizal infection}

At each harvest a fresh root sample from each plant was cleared with $10 \% \mathrm{KOH}$ and stained with trypan blue (Phillips and Hayman, 1970) for assessment of AM infection. AM infection was estimated as frequency of infection ( $\mathrm{F} \%$ ), intensity of infection $(\mathrm{M} \%$ ) and arbuscule frequency $(A \%)$ according to the method of Trouvelot et al (1986).

\section{Carbohydrate analysis}

For the evaluation of the carbohydrate status, the lyophilized stems, roots and leaves of plants harvested at 3, 4, 5 and 10 months after inoculation were ground to a fine powder and stored at $-20{ }^{\circ} \mathrm{C}$ for analysis of soluble (fructose, glucose, sucrose and sorbitol) and insoluble (starch) sugars.

The equivalent of $0.1 \mathrm{~g}$ of fresh matter, after adding $2.5 \mathrm{mg}$ of $\beta$-phenil-glucopyranoside as internal standard, was extracted overnight at room temperature with $7 \mathrm{~mL}$ of $80 \%$ ethanol and $2 \mathrm{~mL}$ of imidazole buffer $0.1 \mathrm{M}, \mathrm{pH} 7$, in order to avoid acid hydrolysis of 
sucrose in fructose and glucose (Bartolozzi et al, 1996). The extract was then centrifuged at $4000 \mathrm{rpm}$ for $10 \mathrm{~min}$. The supernatant was withdrawn and made up to a volume of $10 \mathrm{~mL}$ with $80 \%$ ethanol. Four $\mathrm{mL}$ of this solution were dried by air stream at room temperature and dissolved in $200 \mu \mathrm{L}$ of anydrous pyridine:hexamethyldisilazane:trimethylchlorosilane mixture $(4: 2: 1)$ for $2 \mathrm{~h}$ at $60^{\circ} \mathrm{C}$. The cooled samples were stored at $4{ }^{\circ} \mathrm{C}$ and $3 \mu \mathrm{L}$ were used for the injection into gas chromatograph (GC).

For starch determination the pellet was suspended in $5 \mathrm{~mL}$ of double deionized water and boiled for $1 \mathrm{~h}$. After cooling to room temperature, $1 \mathrm{~mL}$ of sodium acetate buffer $0.1 \mathrm{M}$ at $\mathrm{pH} 5$ and $1 \mathrm{~mL}$ of diastase (20 $\mathrm{mg}$ in $100 \mathrm{~mL}$ of distilled water) were added to each sample and swirled for $24 \mathrm{~h}$ in a dark environmental chamber; $2.5 \mathrm{mg}$ of methyl- $\alpha$-D-mannopyranoside, as quantitative internal standard, were next added to the sample. The supernatant was pooled and diluted to $7.5 \mathrm{~mL}$ with double-deionized water and 1.5 $\mathrm{mL}$ of these solutions were dried in air stream and trimethylsilyted as described earlier.

The GC used was a Chrompack CP 9000 (Chrompack, Middelbung, the Netherlands) equipped with a flame ionization detector and a capillary fusedsilica column ( $25 \mathrm{~m} \times 0.25 \mathrm{~mm}$ ID), coated with CP-Sil$5 \mathrm{CB}, \mathrm{DF} 0.12$. Injector and detector temperatures were $280{ }^{\circ} \mathrm{C}$ and $320{ }^{\circ} \mathrm{C}$, respectively. The following temperature programme was set: $120^{\circ} \mathrm{C}$ for $1 \mathrm{~min}$, followed by $120^{\circ} \mathrm{C}$ to $152{ }^{\circ} \mathrm{C}$ at $8{ }^{\circ} \mathrm{C} / \mathrm{min}, 152{ }^{\circ} \mathrm{C}$ to $176^{\circ} \mathrm{C}$ at $12{ }^{\circ} \mathrm{C} / \mathrm{min}, 176^{\circ} \mathrm{C}$ to $198^{\circ} \mathrm{C}$ at $16^{\circ} \mathrm{C} / \mathrm{min}$, $198^{\circ} \mathrm{C}$ to $238^{\circ} \mathrm{C}$ at $20^{\circ} \mathrm{C} / \mathrm{min}, 238^{\circ} \mathrm{C}$ to $300^{\circ} \mathrm{C}$ at 24 ${ }^{\circ} \mathrm{C} / \mathrm{min}$ and held at $300{ }^{\circ} \mathrm{C}$ for $5 \mathrm{~min}$. Flow rates of $\mathrm{He}$, $\mathrm{H}_{2}$, air and $\mathrm{N}_{2}$ (used as a make-up gas) were 2, 30, 250 and $30 \mathrm{~mL} / \mathrm{min}$, respectively, with a split ratio of $80: 1$. The quantification of each compound was performed using the internal standard calculation method.

\section{Data analysis}

Analysis of variance (ANOVA) was performed and a least significant difference test (LSD) was calculated using General Linear Models (GLM) procedures in the SAS programme (SAS Institute, Cary, NC, USA).

\section{RESULTS}

\section{Arbuscular mycorrhizal infection}

Two months after inoculation, plants of mycorrhizal treatment were well colonized with a F\% ranging from 92 to $98 \%$. The uninoculated plants had no root infection. $M \%$ and $A \%$ increased up to 4 months and then slightly decreased, raising an average of 54.7 and $47.7 \%$ over time.

\section{Plant growth}

The growth-promoting effect of the endophyte was first visually observed at day 45 after inoculation, when AM plants showed a significantly greater height increment as compared to nonmycorrhizal plants (fig 1). The inoculated plants reached the maximum increment at 3 months; afterwards mycorrhization did not further stimulate shoot growth. The development of control plants slowed just after transplanting in greenhouse and successively shoot apices showed a very slow growth activity up to the end of the first vegetative growing season. The increase in shoot length of AM plants was accompanied by a greater number of leaves as compared to that of control plants (fig 2).

Inoculation enhanced root development which was about two times greater in AM plants than control plants during the first vegetative growth.

AM infection stimulated DM accumulation more than non-AM plants (fig 3). Between 2 and 3 months RGR DM of the whole AM-infected plant and of the primary yield components (stem, leaf and root) were significantly greater than those of control plants. In particular, RGR for leaf DM of mycorrhizal plants was more than twice than that for stem and root DM. In contrast, con-
Fig 1. Height increment in inoculated and uninoculated $\mathrm{OH} \times \mathrm{F} 51$ plants up to 140 days after inoculation. Values with different letters differ statistically at $P \leq 0.05$.

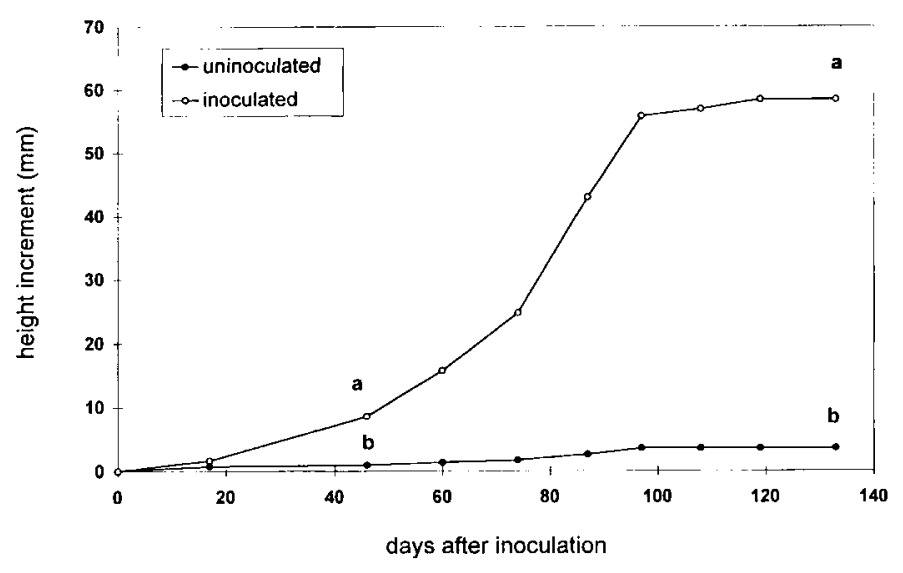




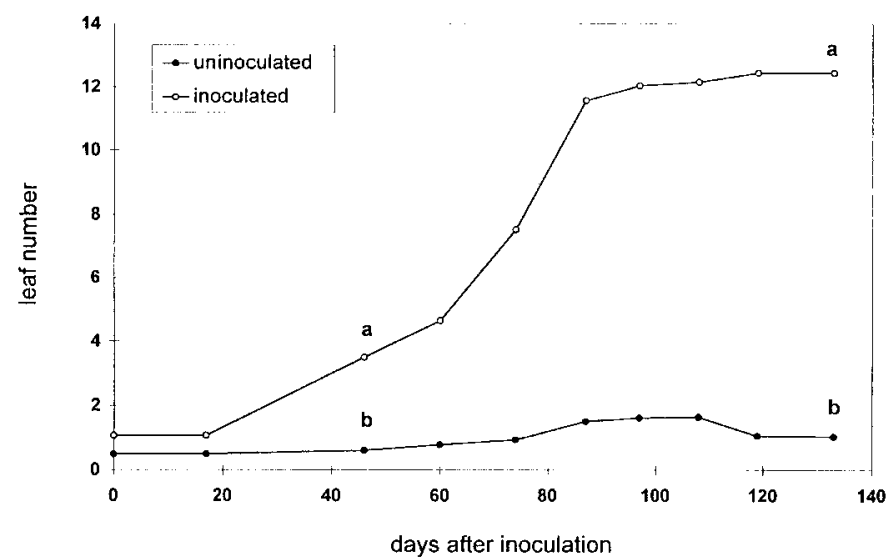

trol plants had approximately similar RGR for leaf, stem and root accretion. Uninfected plants showed a slight increment in the rate of DM accumulation only between 3 and 4 months, while the rate at which AM-infected plants produced dry matter decreased when averaged over time. The AM-enhanced growth was still apparent only for roots between 4 and 5 months as indicated by an almost 20-fold faster RGR DM than that of control plants.

The differences in RGR DM were reflected in the dry matter partitioning between stem, leaf and root (table I). At 3 months after inoculation a higher leaf dry weight (expressed as a proportion of total plant dry weight $[w / w])$ was observed in AM-infected plants than in non-AM plants. Subsequently, relative leaf dry weight of $A M$ plants showed a decrease which resulted in an increase of the relative root and stem dry weight up to month 5 . In contrast to inoculated plants, relative leaf dry weight of non-AM plants was similar to that of stem and root and alteration in dry matter partitioning within plant remained relatively constant during development. At the beginning of the second growing year differences in dry matter partitioning were not detected
Fig 2. Leaf number production of inoculated and uninoculated $\mathrm{OH} \times \mathrm{F} 51$ plants up to 140 days after inoculation. Values with different letters differ statistically at $P \leq 0.05$.

\section{Carbohydrate metabolism}

\section{First growing season}

During the first vegetative growth, sorbitol represented about $50 \%$ of the total concentration of carbohydrates in stems and leaves irrespective of inoculation (tables II and III).

At 3 months mycorrhization determined a significant reduction in total concentration of fructose, glucose and sucrose of $45 \%$ in leaves and of $58 \%$ in stems, although for the individual sugars significant differences were found only for sucrose in leaves and stems and for fructose in stems. Between 3 and 4 months the total concentration of carbohydrates decreased in leaves of uninoculated plants while in stems the depletion of all the soluble sugars was associated with an increase of starch concentration. In contrast, during this period in stems and leaves of $A M$ plants only glucose level decreased, while

Table I. Leaf, stem and root dry weight expressed as a fraction of the total plant dry weight ( $w / w)$ of inoculated (I) and uninoculated (NI) plants during the first growing season (3, 4 and 5 months after inoculation) and at the beginning of the second vegetative growth (10 months after inoculation).

\begin{tabular}{lcccccc}
\hline Months after & \multicolumn{2}{c}{ Leaves } & \multicolumn{2}{c}{ Stems } & \multicolumn{2}{c}{ Roots } \\
inoculation & $I$ & $N I$ & $I$ & $N I$ & $I$ & $N I$ \\
& & & & & & \\
3 & & & & & & \\
4 & 0.553 & 0.296 & 0.246 & 0.311 & 0.201 & 0.353 \\
5 & 0.530 & 0.298 & 0.273 & 0.343 & 0.197 & 0.360 \\
10 & 0.302 & 0.246 & 0.394 & 0.388 & 0.304 & 0.396 \\
& 0.039 & 0.054 & 0.501 & 0.454 & 0.460 & 0.496 \\
\hline
\end{tabular}




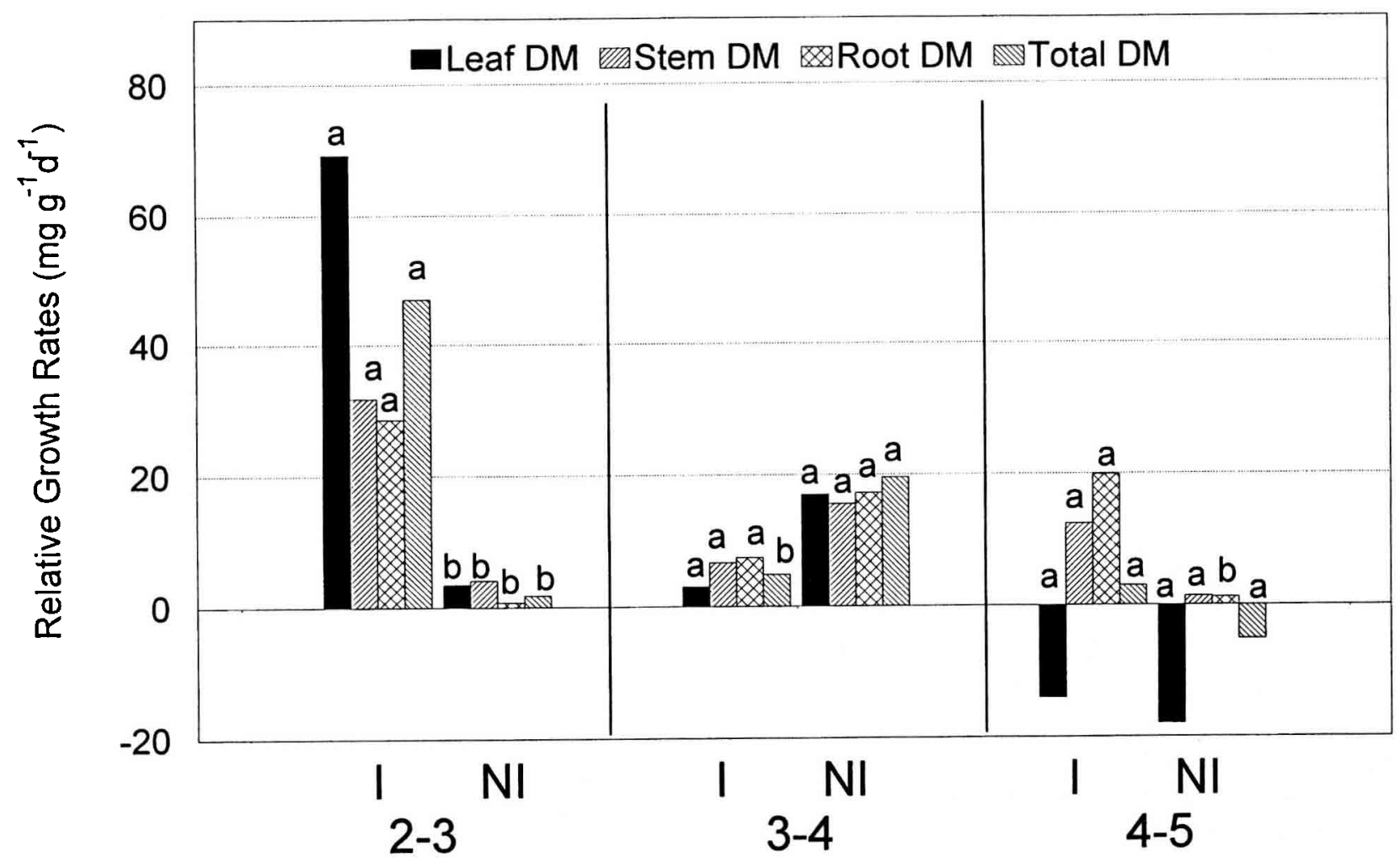

Fig 3. Relative growth rates of leaf, stem and root and total dry matter (DM) of inoculated (I) and uninoculated (NI) and plants between $2-3,3-4$ and $4-5$ months after inoculation. For each interval, values with different letters differ statistically at $P \leq 0.05$.

Table II. Carbohydrate concentrations (as $\mathrm{mg} \mathrm{g}^{-1}$ dry weight) of fructose, glucose, sucrose, sorbitol, total soluble sugars (TSS), starch and total sugars (TS) in leaves of inoculated (I) and uninoculated (NI) $\mathrm{OH} \times \mathrm{F} 51$ plants during the first growing season ( 3,4 and 5 months after inoculation) and at the beginning of the second vegetative growth (10 months after inoculation).

Carbohydrates Treatment

Months after inoculation

$3 \quad 4 \quad 5$

10

\begin{tabular}{|c|c|c|c|c|c|}
\hline \multirow[t]{2}{*}{ Fructose } & 1 & $2.42^{\mathrm{a}}$ & $2.06^{a}$ & $2.56^{a}$ & $3.57^{a}$ \\
\hline & $\mathrm{NI}$ & $3.44^{\mathrm{a}}$ & $2.41^{\mathrm{a}}$ & $3.44^{a}$ & $8.71^{a}$ \\
\hline \multirow[t]{2}{*}{ Glucose } & 1 & $17.16^{a}$ & $5.70^{a}$ & $12.08^{a}$ & $57.12^{a}$ \\
\hline & $\mathrm{NI}$ & $24.68^{a}$ & $5.65^{a}$ & $12.46^{a}$ & $79.64^{a}$ \\
\hline \multirow[t]{2}{*}{ Sucrose } & I & $10.70^{b}$ & $11.24^{a}$ & $9.82^{a}$ & $3.91^{b}$ \\
\hline & $\mathrm{NI}$ & $15.85^{a}$ & $7.66^{b}$ & $10.89^{a}$ & $11.78^{a}$ \\
\hline \multirow{2}{*}{ Sorbitol } & 1 & $57.54^{a}$ & $62.01^{a}$ & $65.54^{a}$ & $22.29 \mathrm{~b}$ \\
\hline & $\mathrm{NI}$ & $54.51^{\mathrm{a}}$ & $44.47^{b}$ & $53.85^{a}$ & $41.73^{a}$ \\
\hline \multirow[t]{2}{*}{ TSS } & 1 & $87.81^{a}$ & $81.00^{a}$ & $90.00^{a}$ & $88.90^{b}$ \\
\hline & $\mathrm{NI}$ & $98.37^{a}$ & $59.83^{b}$ & $80.63^{a}$ & $141.87^{a}$ \\
\hline \multirow[t]{2}{*}{ Starch } & 1 & $17.29^{a}$ & $19.19^{a}$ & $17.66^{a}$ & $53.31^{a}$ \\
\hline & $\mathrm{NI}$ & $21.28^{a}$ & $16.35^{a}$ & $21.43^{a}$ & $40.56^{a}$ \\
\hline \multirow[t]{2}{*}{ TS } & 1 & $105.11^{a}$ & $105.75^{a}$ & $107.66^{a}$ & $142.21^{a}$ \\
\hline & $\mathrm{NI}$ & $119.65^{a}$ & $80.99 b$ & $102.66^{a}$ & $182.43^{a}$ \\
\hline
\end{tabular}

ab For each sugar value within columns followed by the same letters are not significantly different at $P \leq 0.05$. 
Table III. Carbohydrate concentrations (as $\mathrm{mg} \mathrm{g}^{-1}$ dry weight) of fructose, glucose, sucrose, sorbitol, total soluble sugars (TSS), starch and total sugars (TS) in stems of inoculated (I) and uninoculated (NI) OH x F 51 plants during the first growing season ( 3,4 and 5 months after inoculation) and at the beginning of the second vegetative growth (10 months after inoculation).

\begin{tabular}{|c|c|c|c|c|c|}
\hline \multirow[t]{2}{*}{ Carbohydrates } & \multirow[t]{2}{*}{ Treatment } & \multicolumn{4}{|c|}{ Months after inoculation } \\
\hline & & 3 & 4 & 5 & 10 \\
\hline \multirow[t]{2}{*}{ Fructose } & 1 & $1.43^{b}$ & $1.50^{b}$ & $1.69 \mathrm{a}$ & $1.65^{a}$ \\
\hline & $\mathrm{NI}$ & $2.55 \mathrm{a}$ & $2.22 \mathrm{a}$ & $1.94^{\mathrm{a}}$ & $1.80^{\mathrm{a}}$ \\
\hline \multirow[t]{2}{*}{ Glucose } & 1 & $3.75^{a}$ & $2.93^{a}$ & $3.38^{a}$ & $3.30 \mathrm{a}$ \\
\hline & $\mathrm{NI}$ & $5.51^{a}$ & $3.96 \mathrm{a}$ & $3.84^{a}$ & $2.84 \mathrm{a}$ \\
\hline \multirow[t]{2}{*}{ Sucrose } & 1 & $3.08^{b}$ & $4.04^{a}$ & $5.34^{a}$ & $3.28^{a}$ \\
\hline & $\mathrm{NI}$ & $5.05^{a}$ & $3.57^{a}$ & $5.62 \mathrm{a}$ & $1.87^{b}$ \\
\hline \multirow[t]{2}{*}{ Sorbitol } & 1 & $32.04^{a}$ & $35.63 \mathrm{a}$ & $27.74^{a}$ & $6.43^{a}$ \\
\hline & $\mathrm{NI}$ & $30.38^{a}$ & $25.85^{b}$ & $24.88^{a}$ & 4.38 a \\
\hline \multirow[t]{2}{*}{ TSS } & 1 & $40.29^{a}$ & $44.10^{a}$ & $38.13^{a}$ & $14.66^{a}$ \\
\hline & $\mathrm{NI}$ & $43.49^{a}$ & $35.60^{a}$ & 36.28 a & $10.89^{a}$ \\
\hline \multirow{2}{*}{ Starch } & 1 & $15.42^{\mathrm{a}}$ & $27.60^{a}$ & $26.55^{a}$ & $18.01^{a}$ \\
\hline & $\mathrm{NI}$ & $17.95^{a}$ & $23.84^{a}$ & 30.63 a & $18.23^{a}$ \\
\hline \multirow[t]{2}{*}{ TS } & 1 & $55.70^{a}$ & $71.71^{\mathrm{a}}$ & $60.63^{a}$ & $32.67^{a}$ \\
\hline & $\mathrm{NI}$ & $64.63^{a}$ & $59.57^{b}$ & $66.91^{a}$ & $29.12^{a}$ \\
\hline
\end{tabular}

ab For each sugar value within columns followed by the same letters are not significantly different at $P \leq 0.05$.

sucrose slightly increased and fructose remained almost constant. Starch and sorbitol showed an increasing pattern which was more evident in stems than in leaves. As a result, at 4 months, when growth activity arrested, stems and leaves of $\mathrm{AM}$ plants had a significantly higher level of the total carbohydrate concentration $(20-30 \%$, respectively).

As the growing season progressed, differences in carbohydrate pattern were found between leaves and stems irrespective of inoculation. During the interval 4-5 months, a slight decrease of fructose, glucose and sorbitol was still observed in stems of non-AM plants while sucrose and starch increased. In stems of AMinfected plants fructose, glucose and sucrose concentration increased, while the sorbitol and starch level decreased. The glucose increase rate was lower as compared to the decrease rate of the previous period (3-4 months), resulting in a decreasing pattern when averaged over the first growing season. Consequently, at month 5 any significant differences between $A M$ and uninoculated plant stems disappeared.

While a general increment in carbohydrate concentration was found in uninoculated plant leaves between 4 and 5 months, the pattern of total sugar levels slightly decreased when averaged over the first growing season. Mycorrhization caused a low depletion in sucrose and starch concentration in leaves, while sorbitol further increased. Similar to the trend observed in stems, glucose concentration in leaves increased but decreased when averaged over time. As a result, at month 5 differences between sorbitol and the other soluble sugars were more evident in inoculated plants. However, at this harvesting date differences in leaf carbohydrate concentration between $A M$ and non-AM plants disappeared.

During the first vegetative growth (3-5 months) glucose, fructose and sucrose levels detected in roots were significantly higher in control than in AM plants, except at month 5 when glucose levels were similar in all roots (table IV). 
During the first vegetative growth there was a general trend toward a slight decrease in starch level and an increase in soluble sugars in roots of both $A M$ and control plants. This increment was more pronounced for sorbitol in AM plant roots and sucrose in those of control plants. In spite of the changes of individual sugars, total carbohydrate levels were never statistically different.

\section{Second growing season}

At the beginning of the second growing year (month 10), the major components of the total carbohydrates were glucose and starch in the leaves of AM and control plants. Starch was the main carbohydrate recovered in both roots and stems, accounting for $60 \%$ of the sugars, regardless of inoculation.

At month 10 , total soluble sugar concentration in leaves of AM plants was almost two-fold lower than in non-AM plants as a result of significantly lower sucrose and sorbitol levels. In the stems of inoculated plants only sucrose concentration was significantly higher than that of control plants.
Similar levels of sugars were detected in the roots of both inoculated and uninoculated plants.

\section{DISCUSSION}

Mycorrhization appears to play an important role in improving the development of micropropagated Pyrus plant rootstocks, which frequently show a tendency to lapse into arrest of growth after transplanting in nursery conditions.

Inoculation with Glomus sp was effective in enhancing plant growth causing a strong increase in shoot elongation and root length, starting from 45 days after inoculation. The growth-promoting effect of the endophyte was confirmed by the higher RGR DM observed between 2 and 3 months. In AM plants, the greater RGR DM occurred especially for leaves as compared to roots and stems. These differences were reflected as a greater partitioning of dry matter to leaves rather than to roots and to stems occurred in AM plants at month 3 . As the growing season progressed, a decrease in rela-

Table IV. Carbohydrate concentrations (as $\mathrm{mg} \mathrm{g}^{-1}$ dry weight) of fructose, glucose, sucrose, sorbitol, total soluble sugars (TSS), starch and total sugars (TS) in roots of inoculated (I) and uninoculated (NI) $\mathrm{OH} \times \mathrm{F} 51$ plants during the first growing season ( 3,4 and 5 months after inoculation) and at the beginning of the second vegetative growth (10 months after inoculation).

\begin{tabular}{|c|c|c|c|c|c|}
\hline \multirow[t]{2}{*}{ Carbohydrates } & \multirow[t]{2}{*}{ Treatment } & \multicolumn{4}{|c|}{ Months after inoculation } \\
\hline & & 3 & 4 & 5 & 10 \\
\hline \multirow[t]{2}{*}{ Fructose } & 1 & $1.57^{b}$ & $1.87^{b}$ & $2.43^{b}$ & $2.71^{a}$ \\
\hline & $\mathrm{NI}$ & $3.55^{\mathrm{a}}$ & $3.93^{a}$ & $3.99 \mathrm{a}$ & $5.19^{a}$ \\
\hline \multirow[t]{2}{*}{ Glucose } & 1 & $1.86^{b}$ & $3.18^{b}$ & $4.33^{a}$ & $4.34 \mathrm{a}$ \\
\hline & $\mathrm{NI}$ & $4.88^{a}$ & $4.71^{\mathrm{a}}$ & $4.40^{\mathrm{a}}$ & $4.58^{a}$ \\
\hline \multirow[t]{2}{*}{ Sucrose } & 1 & $4.26^{b}$ & $5.38^{b}$ & $5.16^{b}$ & $5.20^{a}$ \\
\hline & $\mathrm{NI}$ & $11.12^{\mathrm{a}}$ & $12.27^{a}$ & $14.53^{a}$ & $7.02^{a}$ \\
\hline \multirow[t]{2}{*}{ Sorbitol } & 1 & 19.99 a & $32.31^{a}$ & $27.63^{a}$ & $3.67^{a}$ \\
\hline & NI & 19.95 a & $21.31^{b}$ & $22.92^{a}$ & $3.36^{a}$ \\
\hline \multirow[t]{2}{*}{ TSS } & I & $27.68 \mathrm{~b}$ & $42.74^{a}$ & $39.54^{a}$ & $15.93^{a}$ \\
\hline & $\mathrm{NI}$ & 39.52 a & $42.20^{a}$ & 45.84 a & $20.14^{a}$ \\
\hline \multirow[t]{2}{*}{ Starch } & 1 & $26.77^{a}$ & $28.77^{a}$ & 24.79 a & $28.76^{a}$ \\
\hline & $\mathrm{NI}$ & 26.89 a & 26.08 a & 22.79 a & $25.75^{a}$ \\
\hline \multirow[t]{2}{*}{ TS } & 1 & $54.45^{a}$ & $71.51^{\mathrm{a}}$ & $64.34 \mathrm{a}$ & $44.69^{a}$ \\
\hline & $\mathrm{NI}$ & $66.40^{a}$ & $68.28^{a}$ & 68.63 a & $45.89 \mathrm{a}$ \\
\hline
\end{tabular}

\footnotetext{
ab For each sugar value within columns followed by the same letters are not significantly different at $P \leq 0.05$.
} 
tive leaf dry weight was observed with a concomitant increase in relative stem and root dry weight. At the end of the first growing season, the daily DM accumulation rate was still high only in the roots of inoculated plants as compared to control ones. Thus, initially AM plants allocated more of their nutritional resources to leaves rather than to stems and roots. Subsequently, there was a trend towards an increase in DM accumulation to roots and to stems at the expense of foliar growth according to Trimble and Knowels (1995). In spite of inoculated plants, RGR DM for leaves, roots and stems of control were similar and very low, although they slightly increased later in the season (4-5 months). As a result, alterations of DM partitioning between stems, roots and leaves were generally small in control plants.

Mycorrhization significantly affected the soluble sugar concentrations while the endophyte did not alter the starch levels as compared to uninfected plants. In fact, at 3 months the levels of soluble sugars in AM plants were generally lower than in control ones, confirming the results of a preliminary study (Rapparini et al, 1994). This indicates a greater demand for carbon to substain the high vegetative growth activity of both shoots and roots. Subsequently (3-4 months), when shoot elongation was still active but slower than before ( 3 months), mycorrhization caused an increase of sorbitol and sucrose levels in stems and leaves and only of sorbitol in roots. All the other soluble sugars showed smaller changes in both treatments.

Sorbitol comprised a great proportion of the total sugar pool in the whole plant and in particular in leaves. Since it is a major final product of photosynthesis (Escobar-Gutiérrez, 1995), its increment in AM plants might be related to a more efficient photosynthetic activity, which exceeds the use of carbon in respiration and in the slowed growth. Besides, since sorbitol represents, together with sucrose, the main form of carbon translocated in many species of Rosaceae (Zimmerman and Ziegler, 1975; Moing et al, 1992), a raise of sorbitol concentration associated with a great partitioning from leaves to roots of AM plants probably indicate an enhanced translocation of carbohydrate towards roots, as reported by Snellgrove et al (1982). This could be related to an increased sink strength of roots for carbon to support the symbiosis and the high root growth rate as reflected by a greater partitioning of total dry matter to roots at the expense of leaves.
At the end of the first vegetative season, when plants arrested their growth, any differences on carbohydrate status between AM and control plants disappeared.

In the second year, the growth promoting effect of mycorrhization was still evident. In fact, an earlier renewal of growth activity was observed in AM plants compared to control plants as reported also for plum rootstock (Fortuna et al, 1992). This effect was associated with an alterated carbon status resulting from the depletion mainly of sucrose and sorbitol levels in the leaves and by the increment of these soluble sugars in the stems as compared to uninfected plants. Since at this time the growth activity just began, no corresponding differences were found in the roots of both treatments.

In conclusion, these results demonstrate that AM fungi enhanced the development of the pear rootstock $\mathrm{OH} \times \mathrm{F} 51$ and altered the carbohydrate metabolism.

In fact, sugar status of the host plant appears to depend not only on the fungus demand, but also on the result of two different physiological mechanisms: i) the biosynthesis of carbohydrates following the fungus-enhanced growth of the photosynthetic system and ii) the utilization of the translocated carbohydrates for maintaining respiratory and growth processes which are stimulated by the endophyte, as suggested by Ocampo and Azcón (1985).

\section{REFERENCES}

Bartolozzi F, Bertazza G, Bassi D, Cristoferi G (1996) Simultaneous GLC determination of soluble sugars and organic acids as trimethylsilyl derivates in apricot fruits. J Chromatogr $[A]$ (in press)

Berta G, Fusconi A, Trotta A, Scannerini S (1990) Morphogenetic modifications induced by the mycorrhizal fungus Glomus strain E3 in the root system of Allium porrum L. New Phytol 114, 207-215

Cooper KM (1984) Physiology of VA mycorrhizal associations. In: VA Mycorrhizae (CL Powell, DJ Bagyaraj, eds), CRC Press, Boca Raton, FL, USA, 155-186

Dixon RK, Garret HE, Fox GS (1988) Carbohydrate relationships of Citrus jambhiri inoculated with Glomus fasciculatum. J Am Soc Hort Sci 113, 239242

Escobar-Gutiérrez AJ (1995) Photosynthèse, partition du caron et métabolisme du sorbitol dans les feuilles adultes de pêcher (Prunus persica (L) Batsch). Thèse de docteur de l' Université de Poitiers, Poitiers, France 
Fortuna P, Citernesi S, Morini S, Giovannetti M, Loreti $F$ (1992) Infectivity and effectiveness of different species of arbuscular mycorrhizal fungi in micropropagated plants of $\mathrm{MrS} 2 / 5$ plum rootstock. agronomie 12, 825-829

Gianinazzi S, Gianinazzi-Pearson V, Trouvelot A (1989) Potentialities and procedures for the use of endomycorrhizas with special emphasis on high value crops. In: Biotechnology of Fungi for Improving Plant Growth (JM Whipps, RD Lumdsen, eds), Cambridge University Press, Cambridge, UK, 41-45

Harris D, Paul EA (1987) Carbon requirements of vesicular-arbuscular mycorrhizae. In: Ecophysiology of Mycorrhizal Plants (GR Rafir, ed), CRC Press, Boca Raton, FL, USA, 93-104

Moing A, Carbonne F, Rashad MH, Gaudillére JP (1992) Carbon fluxes in mature peach leaves. Plant Physiol 100, 1878-1884

Nemec S, Vu JCV (1990) Effects of soil phosphorus and Glomus intraradices on growth, nonstructural carbohydrates, and photosynthetic activity of Citrus aurantium. Plant Soil 128, 257-263

Ocampo JA, Azcón R (1985) Relation between the concentration of sugars in the roots and VA mycorrhizal infection. Plant Soil 86, 95-100

Phillips JM, Hayman DS (1970) Improved procedures for clearing roots and staining parasitic and vesicu- lar-arbuscular mycorrhizal fungi for rapid assessment of infection. Trans Br Mycol Soc 55, 158-161

Rapparini F, Baraldi R, Bertazza G, Branzanti B, Predieri S (1994) Vesicular-arbuscular mycorrhizal inoculation of micropropagated fruit trees. $J$ Hort Sci 69, 1101-1109

Snellgrove RC, Splittstoesser WE, Stribley DP, Tinker PB (1982) The distribution of carbon and the demand of the fungal symbiont in leek plants with vesicular-arbuscular mycorrhizas. New Phytol 92, 75-87

Trimble MR, Knowles NR (1995) Influence of vesicular-arbuscular mycorrhizal fungi and phosphorus on growth, carbohydrate partitioning and mineral nutrition of greenhouse cucumber (Cucumis sativus $\mathrm{L}$ ) plants during establishment. Can J Plant Sci 75, 239-250

Trouvelot A, Kough JL, Gianinazzi-Pearson V (1986) Mesure du taux de mycorhization VA d'un système radiculaire. Recherche de méthodes ayant une signification fonctionnelle. In: Physiological and Genetical Aspects of Mycorrhizae (V GianinazziPearson, S Gianinazzi, eds), INRA Press, Paris, France, 217-221

Zimmermann $\mathrm{MH}$, Ziegler $\mathrm{H}$ (1975) List of sugar alcohols in sieve tube exudates. In: Encyclopedia of Plant Physiology (MH Zimmermann, JA Milburn, eds), New series, Vol 1, Springer-Verlag, Berlin, Germany, 480-503 